\begin{tabular}{|l|l|l||}
\hline \multicolumn{2}{|c|}{ PublisherInfo } \\
\hline \hline PublisherName & $:$ & BioMed Central \\
\hline \hline PublisherLocation & $:$ & London \\
\hline \hline PublisherImprintName & $:$ & BioMed Central \\
\hline \hline
\end{tabular}

\title{
Buffers for hemofiltration
}

\begin{tabular}{||l|l|l||}
\hline \multicolumn{2}{|c||}{ ArticleInfo } \\
\hline \hline ArticleID & $:$ & 4178 \\
\hline \hline ArticleDOI & $:$ & $10.1186 /$ ccf-1999-2422 \\
\hline \hline ArticleCitationID & $:$ & 2422 \\
\hline \hline ArticleSequenceNumber & $:$ & 37 \\
\hline \hline ArticleCategory & $:$ & Paper Report \\
\hline \hline ArticleFirstPage & $:$ & 1 \\
\hline \hline ArticleLastPage & $:$ & 4 \\
\hline \hline & & RegistrationDate : 1999-12-17 \\
ArticleHistory & $:$ & OnlineDate $\quad$ 1999-12-17 \\
\hline \hline ArticleCopyright & $:$ & Current Science Ltd1999 \\
\hline \hline ArticleGrants & $:$ & \\
\hline \hline ArticleContext & $:$ & 1305422 \\
\hline \hline
\end{tabular}




\section{Keywords}

Acetate, acute renal failure, bicarbonate, continuous veno-venous hemofiltration, lactate-based hemofiltration

\section{Comments}

The use of lactate, acetate or bicarbonate replacement buffers in CVVH offer no survival advantages in this prospective sequential assigned study. Although the authors emphasize the statistically significant improvements in $\mathrm{pH}$ during $\mathrm{CVVH}$ with bicarbonate and lactate buffer solutions over acetate, clinical significance appears to have been ignored. It is difficult to believe that a $\mathrm{pH}$ at the lower limit of the normal range, seen with the use of acetate buffer, could account for the clinically and statistically significant reduction in cardiac index seen in this group, when compared to stable hemodynamics in the other two groups. Alternative explanations such as reductions in ATP production following high acetate concentrations are more likely.

\section{Introduction}

Continuous veno-venous hemofiltration $(\mathrm{CVVH})$ requires replacement buffer solutions as a consequence of bicarbonate losses during treatment of acute renal failure (ARF). Acetate and L-lactate solutions have traditionally been used, because of their stability during manufacture and storage, and are metabolized in the liver and muscle to bicarbonate on an equimolar basis. However, metabolism may be impaired during critical illness, resulting in the worsening of acidosis and cardiovascular depression. Consequently, the use of bicarbonate-based dialysate solutions has been explored, although commercial supplies have, until recently, been hindered due to stability problems during manufacture and storage.

\section{Aims}

To compare the use of lactate, acetate and bicarbonate replacement buffer solutions on acid-base status and hemodynamics in patients requiring $\mathrm{CVVH}$. 


\section{Methods}

Patients with ARF were sequentially assigned to receive lactate (52 patients), acetate (32 patients) or bicarbonate (48 patients) replacement buffer solutions during CVVH. Another 76 patients were excluded from analysis because of a previous diagnosis of renal failure, or death within $48 \mathrm{~h}$. Hemodynamic measurements using a Swan-Ganz catheter were performed if clinically indicated.

\section{Results}

Baseline demographics and patients excluded from analysis were similar in the 3 groups. There was no difference in mortality between the 3 groups even if analysis was performed on an intent-to-treat basis. Baseline acid-base parameters were comparable in the 3 groups but by the second day of CVVH there were statistically significant increases in serum bicarbonate and $\mathrm{pH}$ in the lactate and bicarbonate groups. The incidence of lactic acidosis was not increased in the lactate-buffer group. Cardiac index was significantly worse in the acetate group after $48 \mathrm{~h}$ with no differences seen in the lactate and bicarbonate groups.

\section{Discussion}

Despite their superior stability during manufacture and storage, both lactate and acetate buffer solutions may be associated with adverse effects on acid-base status and hemodynamics. The advent of commercially available bicarbonate buffer solutions offers an alternative, although effects on outcome remain controversial and are far from proven in favor of bicarbonate solutions. This paper similarly shows no outcome advantage between the various buffer solutions and uremia, fluid balance and electrolytes were controllable with CVVH in all 3 groups. Statistically significant improvements in $\mathrm{pH}$ were seen in the lactate and bicarbonate buffer groups.

\section{Additional information}

There is an accompanying editorial which summarizes the benefits of bicarbonate-buffer solutions, and gives experimental evidence refuting many of the proposed theoretical negative effects of administration of bicarbonate buffer. 


\section{References}

1. Heering P, Ivens K, Thumer O, Morgera S, Heintzen M, Passlick-Deetjen J, Willers R, Strauer BE, Grabensee B: The use of different buffers during continuous hemofiltration in critically ill patients with acute renal failure. Intensive Care Med. 1999, 25: 1244-1251.

This PDF file was created after publication. 